\title{
Aplikasi Profil Perusahaan Digital Berbasis Web
}

\author{
Annisa Mutia Putri ${ }^{1}$; Ire Puspa Wardhani ${ }^{2}$; Susi Widayati ${ }^{3}$ \\ ${ }^{1}$ INSTITUT TEKNOLOGI INDONESIA \\ ${ }^{2,3}$ STMIK JAKARTA STI\&K \\ 2irepuspa@gmail.com
}

\begin{abstract}
Alternatives to promoting companies with a variety of products, besides being able to reduce paper use which has an impact on promotion costs, and creating a wider market, are the main reasons why this research was conducted. There are two types of websites that can be used in business development, namely online store websites and company profile websites. The purpose of digital company profiles is to display company profiles and build credibility in cyberspace. Digital company profile does not bring revenue directly like online store websites, but digital website-based company profiles become a more accurate and trusted source of information. Through a digital company profile, a better business image can be built and entrepreneurs can show the world that the goods and products offered are of good quality. This digital company profile is a promotional media campaign that is more effective and efficient. Website-based Digital Company Profile application, as a means of promotion, is made with the Design and Development of Multimedia Systems that integrate its components. The end result of this application is in the form of files that can be applied in the form of a disk and uploaded on the website.
\end{abstract}

Keywords: Digital Company Profile Application, WEB, Multimedia

\begin{abstract}
ABSTRAK
Alternatif mempromosikan perusahaan dengan produk-produknya, mengurangi penggunaan kertas yang imbasnya pada biaya promosi, dan menciptakan pasar yang lebih luas, menjadi alasan utama mengapa penelitian ini dibuat. Terdapat dua jenis website untuk mengembangkan bisnis, yaitu website toko secara online dan website profil perusahaan. Tujuan dari profil perusahaan digital adalah untuk menampilkan profil perusahaan serta membangun kredibilitas dalam dunia maya. Profil perusahaan Digital memang tidak mendatangkan revenue secara langsung seperti website toko online, namun profil perusahaan digital berbasis website menjadi sumber informasi yang lebih akurat dan terpercaya. Melalui profil perusahaan digital dapat dibangun citra bisnis lebih baik dan pengusaha dapat menunjukkan kepada dunia bahwa barang serta produk yang ditawarkan memiliki kualitas yang baik. Profil perusahaan digital ini adalah sebuah media publikasi promosi yang lebih efektif dan efisien. Aplikasi Profil Perusahaan Digital berbasis website, sebagai sarana promosi ini, dibuat dengan metode Perancangan dan Pengembangan Sistem Multimedia yang mengintegrasikan komponen-komponennya. Hasil akhir Aplikasi ini berbentuk file-file yang bisa diaplikasikan dalam bentuk Piringan Cakram dan diunggah dalam situs website.
\end{abstract}

Kata kunci: Aplikasi Profil Perusahaan Digital, Website, Multimedia 


\section{PENDAHULUAN}

Dalam memenuhi kebutuhannya, manusia mencari dan memilih produsen dan pemasar produk barang dan jasa yang sesuai dengan kebutuhannya tersebut. Namun banyak dari produsen ataupun pemasar yang tidak memperhatikan bagaimana memenuhi kebutuhan tersebut, bagaimana menawarkan produk yang dimiliki dan dihasilkannya dalam usaha memenuhi kebutuhan itu. Salah satunya adalah berpromosi, banyaknya yang terkesan asal-asalan terutama di kategori usaha mikro. Ketidakcukupan biaya dalam pengembangan promosi dan banyaknya saingan melandasi terjadinya proses promosi yang kurang profesional. Padahal, proses promosi itu sendiri merupakan ujung tombak keberhasilan usaha yang langsung menghubungkan antara konsumen dengan produk-produk yang dihasilkan oleh produsennya ataupun para pemasar produk. Jika keindahan dari proses promosi itu sendiri sudah tidak diperhatikan, sehebat apapun produk yang dihasilkan akan nampak biasa saja dan malah mungkin terlihat seperti banyak cacatnya. Mempelajari E-Commerce sebenarnya cukup mudah, karena tidak jauh berbeda dengan pemahaman tentang bagaimana perdagangan atau bisnis selama menjalankan ini. Perbedaannya adalah keterlibatan teknologi komputer dan telekomunikasi secara intensif sebagai sarana untuk lakukan dua hal utama [1]: a. Memproses data mentah menjadi informasi yang dapat digunakan bersama oleh bisnis dan konsumen b. Mendistribusikan data atau informasi dengan cepat dan efisien untuk semua komponen bisnis yang membutuhkan. Seiring dengan berjalannya waktu, peningkatan kapasitas bisnis, perkembangan teknologi dan juga dengan adanya inovasi bisnis serta kemudahan dalam memperoleh informasi tentang produk tersebut, terutama bagi mereka yang tinggal di kota - kota besar sangat menginginkan kecepatan dan kenyamanan dalam memperolehnya karena tingkat mobilisasinya yang tinggi. Butuh segalanya tersaji dengan cepat, efisien, namun tetap dimanjakan dalam penampilannya. Mereka lebih tertarik pada sistem penjualan langsung yang terbatas pada cakupan daerah yang menjadi target pasar. Banyaknya cara berpromosi yang telah ada masih mengandalkan materi cetak. periklanan adalah segala bentuk penyajian non personal, promosi dan ide, barang ataupun jasa oleh sponsor tertentu yang memerlukan pembayaran [2]. Menurut Kotler, memahami bauran pemasaran adalah seperangkat alat pemasaran yang digunakan perusahaan untuk terus mencapai pemasarannya tujuan di pasar sasaran. Bauran Pemasaran adalah sebuah kombinasi variabel yang dapat dikontrol oleh perusahaan untuk mempengaruhi respons konsumen dalam sasaran pasar. Variabel atau aktivitas perlu dilakukan digabungkan dan dikoordinasikan oleh perusahaan sebagai seefektif mungkin, dalam kegiatan pemasarannya. Elemen keempat adalah pasokan produk, struktur harga, promosi, dan distribusi sistem. Keempat elemen dari bauran pemasaran atau dapat disebut 4P (Produk, Harga, Tempat, dan Promosi) [4]. Berkembangnya sistem penjualan melalui internet selain secara konvensional, memunculkan cara berpromosi secara digital yang memudahkan perusahaanperusahaan mikro dan para pemasar dalam mempromosikan produknya dengan cara yang lebih interaktif dan lebih efisien dari segi biaya dan dari segi cakupan pangsa pasarnya [3]. Mereka mempunyai kesempatan yang lebih besar untuk memasarkan lebih luas lagi dan dengan kondisi modal yang tidak besar. Berbagai alasan lain mengapa aplikasi ini berbasis website adalah berbagai macam segmentasi bisnis atau terget pasar yang semakin luas, tidak perlu adanya tatap muka dalam melakukan transaksi atau promosi, sebagai sarana yang tepat untuk promosi, karena selalu online 24 jam non stop, meningkatkan performance suatu perusahaan, lembaga, atau organisasi dan dapat menjadi identitas yang unik bagi perusahaan di dunia internet. Website tidak hanya dapat menghemat waktu dan tempat, tapi juga biaya murah serta dapat diakses darimana saja. Ketika media digital semakin terintegrasi ke dalam kehidupan konsumen, kebebasan mereka dalam menciptakan perasaan terungkap dan semakin tidak berdaya dalam menghadapi persaingan [5]. Misalnya, tekanan untuk 
mempertahankan profil perusahaan aktif dan memelihara hubungan melalui platform online dapat menghasilkan banyak ketidak puasan [6].

\section{METODE PENELITIAN}

Pada penelitian ini digunakan metode penelitian yang terlihat pada gambar-1 berikut ini:

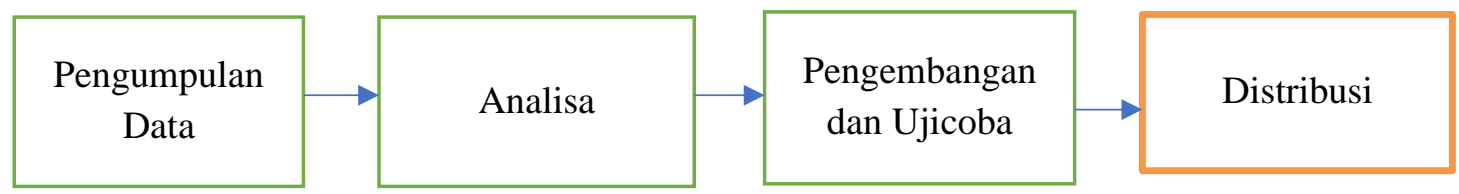

Gambar 1. Tahap Metode Penelitian

1. Pengumpulan Data; Pengumpulan data yang dilakukan pada penelitian ini berbentuk studi lapangan, seperti yang dilakukan dengan pengamatan langsung pada objek yang ada pada badan atau instansi terkait, untuk mendapatkan data-data yang diperlukan. Kemudian dilakukan Studi Kepustakaan, dilakukan dengan cara membaca buku-buku yang berkaitan , mencari di perpustakaan dan mencari situs-situs yang berkaitan sehingga dapat dijadikan referensi dalam penelitian ini.

2. Analisa data dilakukan dengan mengolah semua data-data yang diperoleh dan dikumpulkan. Dan Analisa yang diperoleh atas data-data yang dikumpulkan adalah:

a. Sulitnya memperoleh informasi tentang perusahaan dan produk-produk yang dihasilkannya bila tidak ada alat promosi, termasuk didalamnya berbentuk iklan dan profil perusahaan adalah salah satu alat tersebut.

b. Kurangnya minat perusahaan dan pemasar barang terhadap bentuk profil perusahaan karena biaya pembuatannya yang besar, bentuknya yang tidak ringkas serta perolehannya yang memakan waktu cukup lama

c. target pasar yang terbatas pada produk promosi yang ada, walaupun lengkap informasi yang ditampilkan

\section{PERANCANGAN APLIKASI}

Pengembangan aplikasi; Aplikasi dikembangkan dengan menggunakan metode pengembangan multimedia yang mempunyai 5 tahapan terlihat pada gambar-2 dalam proses rancang bangunnya, yaitu:

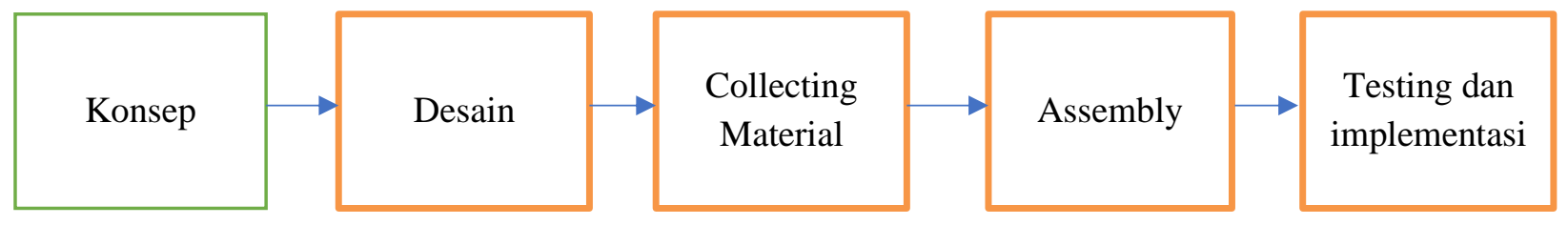

Gambar 2. Tahap Rancang Bangun Aplikasi

a. Konsep ( Concept ); Pada tahapan ini ada 2 hal yang dilakukan, yaitu membuat tujuan dari aplikasi yang dibuat dan mendeskripsikannya.

b. Rancangan ( Design ); Pada tahapan ini, membuat spesifikasi rancangan dari aplikasi yang akan dibuat berbentuk Ruang Cerita, Diagram Alir, Diagram Struktur Navigasi, Digram Transisi dan Perancangan Tampilan. 
c. Pengumpulan Bahan/Materi ( Collecting Material ); Materi/bahan yang merupakan objek multimedia, dikumpulkan dalam bentuk-bentuk yang sudah jadi hasil pembuatan objek sebelumnya ataupun hasil rekayasa objec sehingga memenuhi standar kebutuhan multimedia.

d. Pembuatan (Assembly); merupakan sebuah tahap dimana seluruh objek multimedia yang ada di tahap sebelumnya dikumpulkan dan disatukan lalu dibuat aplikasi, sesuai dengan spesifikasi yang telah dibuat dalam tahap konsep dan perancangan.

e. Pengujian ( Testing ); pengujian dilakukan sendiri dan pihak-pihak lain untuk melihat apakan aplikasi ini sudah sesuai dan menjawab kebutuhan yang ada. Berikutnya aplikasi multimedia disebarluaskan dan juga merupakan tahap evaluasi serta implementasi aplikasi multimedia ini dilakukan.

Setelah semua tahapan dilakukan maka suatu hasil atas penelitian ini menjadi hal penting dan hasilnya adalah aplikasi ini telah sesuai dengan tujuan yang diharapkan.

\section{PERALATAN HARDWARE DAN SOFTWARE}

Dalam penelitian ini, perangkat yang digunakan dalam pengembangan aplikasi pada penelitian ini adalah:

1. Perangkat Keras berbentuk Komputer Lipat berprosesor Intel Pentium 4 Core2Duo, RAM 2 Gbyte, HD $500 \mathrm{~Gb}$, dan ber-VGA Card NVIDIA GeForce GT 520 bermemory 1 Mbyte.

2. Perangkat Lunak Pengembangan Aplikasi Animasi Adobe Flash CS5 dan pendukung lainnya seperti Adobe Photoshop CS5.

\section{HASIL DAN PEMBAHASAN}

Penelitian yang telah dilakukan menghasilkan usulan pembuatan aplikasi yang dibuat dengan metode Perancangan dan Pengembangan Sistem Multimedia, yang tahapannya adalah:

a. Konsep Pengembangan Aplikasi:

Pada pengembangan aplikasi, target audiens atau yang akan menggunakan nantinya adalah siapa saja yang dapat mengoperasikan komputer. Dan penjelasan detai dapat dilihat pada tabel 1 berikut ini:

Tabel 1. Tabel Konsep Pengembangan Aplikasi

\begin{tabular}{|l|l|l|}
\hline No. & \multicolumn{1}{|c|}{ Subyek } & \multicolumn{1}{c|}{ Deskripsi } \\
\hline 1. & Target Audiens / User & Umum, usia anak hingga dewasa \\
\hline 2. & Jenis Aplikasi & Aplikasi Interaktif \\
\hline 3. & Spesifikasi Komputer Minimum & sor ( Intel Pentium IV Dual Core 1,6 GHz ) \\
& & - Memory ( 1 Gb ) \\
& & - Harddisk ( 120 Gb ) \\
& & - VGA ( 128 MB ) \\
& & Monitor \\
& & Speaker \\
& & Mouse \\
& & Keyboard \\
\hline 4. & Tujuan Pembuatan Aplikasi & Sebagai alat bantu pemasaran, khususnya peminat \\
& & produk tertentu, spt T-Shirt, Hijab, . \\
\hline
\end{tabular}

b. Perancangan:

Dalam perancangan aplikasi, adab beberapa rancangan yang dapat dijelaskan disini, yaitu perancangan Struktur Navigasi dan Perancangan Tampilan sebagai sampel dari keseluruhan rancangan aplikasi pada penelitian ini. 
1. Perancangan Navigasi Aplikasi, dimulai dari Menu Pembuka, dst.

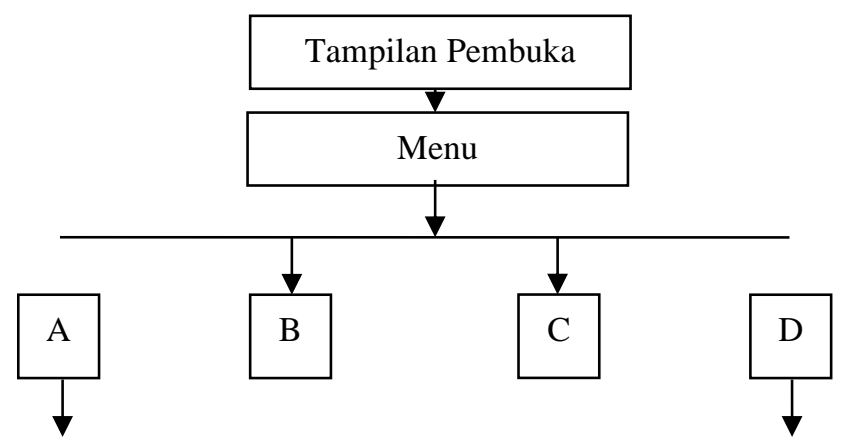

Gambar 1. Struktur Navigasi Menu Pembuka

Keterangan Gambar:

- Pointer A : Navigasi ke Menu Profil Perusahaan

- Pointer $B$ : Navigasi ke Menu Katalok Produk

- Pointer $C$ : Navigasi ke Menu Contact Person

- Pointer D : Navigasi ke Menu Order

2. Tampilan Aplikasi:

Beberapa tambilan yang dicontohkan pada penulisan ini adalah tampilan Cover Aplikasi, tampilan daftar isi dan tampilan halaman isi profile.

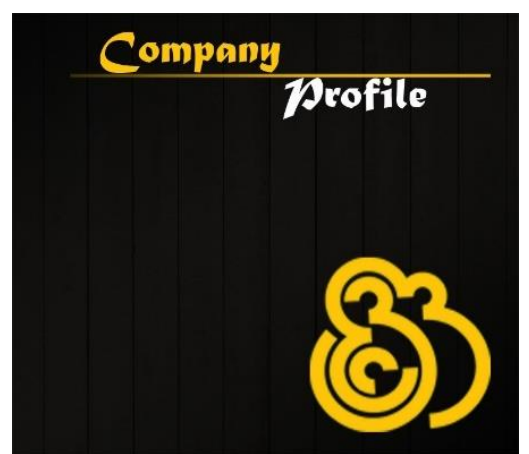

Gambar 2. Cover Aplikasi

Gambar 2 merupakan tampilan halaman Cover dari Aplikasi yang dibuat menggambarkan tentang apa bentuk aplikasi ini dan perusahaan yang mengeluarkannya. Yang berikutnya adalah bagian Isi Aplikasi yang terdiri dari tampilan daftar isi dan tampilan halaman profile.

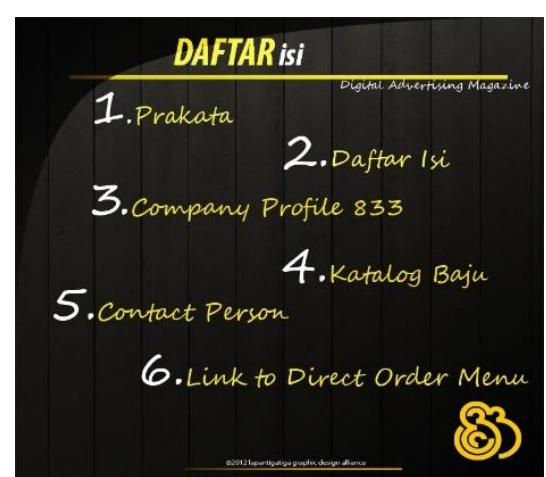

Gambar 3. Isi Aplikasi 
Dari gambar 3 diatas terlihat daftar isi dari keseluruhan aplikasi yang secara analogi sama dengan isi dari profil perusahaan pada umumnya.

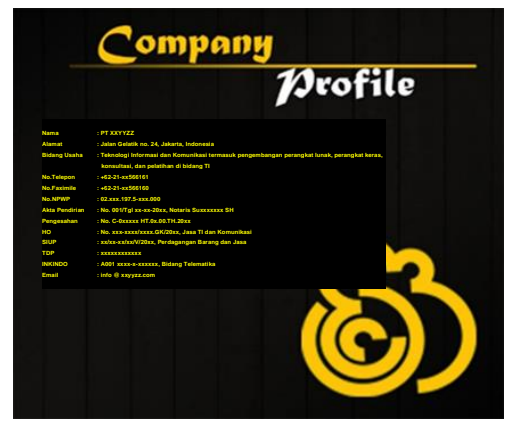

Gambar 4. Halaman profile Aplikasi

Dan gambar 4 merupakan tampilan profile perusahaan yang terdiri dari data-data perusahaan nama, alamat dan alamat surel perusahaan, bidang usaha, legalitas perusahaan (Nomor Pokok Wajib Pajak, Tanda Daftar Perusahaan, Surat Ijin Usaha Perusahaan, dsb), yang menjelaskan tentang identitas perusahaan tersebut, berikut dengan logo perusahaan. Dan pada profile perusahaan dapat dimasukkan pula gambar-gambar produk yang ditawarkan agar lebih menarik.

c. Testing:

Untuk memastikan apakah aplikasi sesuai dengan rancangan maka dilakukan tes yang bentuknya adalah Tes Penampilan dan Black Box Test pada lingkungan terbatas. Hasilnya adalah:

a. Rangkaian Tampilan sesuai dengan navigasi perancangan.

b. Komponen Multimedia yang digunakan terangkai secara lengkap dan berfungsi dengan baik.

c. Besar memory total yang dibutuhkan untuk aplikasi ini adalah sebesar $1096 \mathrm{~Kb}$, dengan rincian, file utama $262 \mathrm{~Kb}$, dan file pendukung sebesar $834 \mathrm{~Kb}$.

d. Aplikasi berjalan dengan baik pada spesifikasi komputer minimum yang ditetapkan saat perancangan.

e. Distribusi: Format yang disiapkan untuk pendistribusian akhir dapat disesuaikan karena bentuk akhirnya yang masih berbentuk file sehingga bisa berbentuk CD untuk Aplikasi Komputer dan dapat diunggah ke situs sebagai materi online ataupun materi yg bisa diunduh.

\section{KESIMPULAN DAN SARAN}

Dari hasil penelitian berupa aplikasi profil perusahaan digital sebagai berikut:

\section{Kesimpulan}

1. Dari penelitian yang dilakukan menghasilkan sebuah solusi yang memberikan Alternatif bentuk promosi perusahaan, mengurangi penggunaan kertas yang imbasnya pada biaya promosi, dan menciptakan pasar yang lebih luas.

2. Setelah semua tahapan dilakukan maka suatu hasil penelitian ini adalah aplikasi ini telah sesuai dengan tujuan yang diharapkan. Dan Aplikasi ini memiliki bentuk yang dapat diatur sesuai kebutuhan, sehingga mudah mendistribusikannya dan tentunya memperluas pasar yang ingin diraih.

3. Aplikasi dibuat dengan menyesuaikan besarnya lebar pita yang ada di Indonesia sehingga kemampuan aplikasi belum maksimal menerapkan teknologi multimedia. 


\section{Saran}

Perlu pengembangan lebih lanjut dari aplikasi ini disesuaikan besarnya lebar pita yang ada di Indonesia sehingga kemampuan aplikasi bisa dimaksimalkan penerapan teknologi multimedia. Seperti pemanfaatan Animasi yang lebih canggih dan Video yang lebih menarik.

\section{DAFTAR PUSTAKA}

[1] Kosiur, David. (1997). Understanding Electronic Commerce - How Online Transactions can Grow Your Business. Microsoft Press. Redmond. Washington.

[2] Farola, Yudi, 2005, Analisis Efektivitas Iklan Sebagai Salah Satu Strategi Pemasaran Perusahaan Percetakan dan Penerbitan PT. Rambang Dengan Menggunakan Metode Epic Model, Jurnal Manajemen dan Bisnis Sriwijaya, Volume 3, Nomor 6.

[3] Suyanto, Muhammad, 2003, Multimedia Alat untuk Meningkatkan Keunggulan bersaing, Penerbit Andi. Yogyakarta

[4] Kotler, Philip. 2005. Manajamen Pemasaran, Jilid 1 dan 2. Jakarta: PT. Indeks Kelompok Gramedia.

[5] Hoffman, Donna L., Thomas P. Novak, and Alladi Venkatesh (2004), "Has the Internet Become Indispensable?," Communications of the ACM, 47, 7, 37-42.

[6] Labrecque, Lauren I., Ereni C. Markos, and George R. Milne (2011), "Online Personal Branding: Processes, Challenges, and Implications,” Journal of Interactive Marketing, 25, 1, $37-50$. 